\section{In Vitro Fatigue Resistance of Teeth Restored With Bulk Fill versus Conventional Composite Resin}

Gabrielle Branco Rauber ${ }^{1}$, Jussara Karina Bernardon'1, Luiz Clovis Cardoso Vieira ${ }^{1}$, Hamilton Pires Maia ${ }^{1}$, Françoá Horn² ${ }^{2}$ Carlos Rodrigo de Mello Roesler²
'Department of Operative Dentistry, UFSC - Universidade Federal de Santa Catarina, Florianópolis, SC, Brazil ${ }^{2}$ Mechanical Engineering Department, Biomechanics Engineering Laboratory, University Hospital, UFSC - Universidade Federal de Santa Catarina, Florianópolis, SC, Brazil

Correspondence: Dra. Gabrielle Branco Rauber, Rua Jornalista Tito de Carvalho, 155, Bloco Nápoles, Apto 406, Carvoeira, Florianópolis, SC, Brasil. Tel: +55-48-9125-1783. e-mail: gabi_rauber@hotmail.com

Key Words: composite resin, bulk fill, fatigue resistance.

\section{Introduction}

The development of dental products, especially composite resin, aims at reducing the restorative steps by simplifying the procedures and shortening the clinical time. The bulk fill composite resin promises cavity fill in a single increment, reducing the clinical time spent on a restoration compared with a conventional incremental placement of composite resin.

Among these bulk-fill composite resins, Tetric N-Ceram Bulk Fill (Ivoclar Vivadent AG, Schaan, Liechtenstein) is a hybrid resin for direct restorations in posterior teeth, which can be applied in single increments of up to $4 \mathrm{~mm}$ deep. It is composed by $21 \mathrm{wt} \%$ resinous matrix (glycol dimethacrylate monomers), 61 wt\% of filler particles (barium, ytterbium fluoride, trioxides), 17 wt $\%$ of polymer filler and 1 wt $\%$ of initiators, stabilizers and pigments. Laboratory studies report that the polymerization shrinkage is smaller and polymerization depth is greater for bulk fill composite resins, which allows their insertion in increments of up to $4 \mathrm{~mm}$ deep $(1,2)$.

In the oral cavity, apart from the mechanical load, restorative materials are exposed to different environmental conditions. Fatigue resistance in dental restorations is influenced by the degradation in water at $37{ }^{\circ} \mathrm{C}$ and cyclic masticatory forces (3). Therefore, it is important to test the mechanical properties of dental materials under masticatory forces and their fatigue resistance (4). Survival fatigue is defined as the number of mechanical load cycles that a material can withstand before fracturing. Literature reports have shown that materials that exhibit high initial resistance do not always have high resistance to fatigue $(5,6)$. Therefore, it seems appropriate that the strength of teeth restored with dental materials should be measured using a dynamic mechanical test rather than static tests (6-24).

The aim of this paper was to test the fatigue resistance of teeth restored with bulk fill composite resin using two cavity insertion techniques and compare these results with those of teeth restored with the incremental insertion of a composite resin and unprepared sound teeth. The tested null hypotheses were: 1 . Restored teeth and unprepared sound teeth have the same resistance to fatigue; 2 . Teeth restored with bulk fill composite resin inserted in a single increment and three increments show the same resistance to fatigue; 3 . Teeth restored with a bulk fill composite resin in both insertion techniques show the 
same fatigue resistance compared with teeth restored with a conventional incremental technique of composite resin.

\section{Material and Methods}

This study was approved by the local Ethics Committee on Human Research (\#863.746). Twenty-eight maxillary premolars extracted for orthodontic reasons were selected. As inclusion criteria, the teeth had to be free of cavities and cracks, have similar shape and size with an intercuspal distance between 4-6 $\mathrm{mm}$, measured with a digital caliper. Soft tissue was removed using periodontal curettes and pumice prophylaxis and the teeth were stored in $0.1 \%$ thymol solution.

\section{Specimen Preparation}

The roots of all teeth were embedded in a $25 \mathrm{~mm}$ diameter cylinder using a self-curing acrylic resin. The insertion of the teeth was carried out using a dental surveyor so that the occlusal surface of the tooth remained parallel to the cylinder base and the cementoenamel junction (CEJ) was positioned $2 \mathrm{~mm}$ above the resin level to simulate the bone tissue.

Two impressions of the occlusal surface of each tooth were made using polyvinylsiloxane Express XT (3M-ESPE, St. Paul, MN, USA). The first mold was sectioned in a buccopalatal direction and provided guidelines for a depth check of the cavity's occlusal box. The second mold was then used to reproduce the original shape and volume of the occlusal surface of each tooth.

Teeth were randomly divided into 4 groups (Table 1). In groups I, BF3 and BF1, cavities were prepared to simulate class II MOD cavities using the diamond bur no. 3131 (KG Sorensen, Cotia, SP, Brazil) at high speed under constant cooling with water and air. A new diamond bur was used for every preparation. Tooth preparation was standardized

Table 1. Group division

\begin{tabular}{lc}
\hline Group & $\begin{array}{c}\text { Restorative technique } \\
\text { and composite resin }\end{array}$ \\
\hline Control (C) & Sound unprepared teeth \\
& Class II cavity (MOD) \\
with conventional \\
incremental insertion. \\
Class II cavity (MOD) with \\
insertion of composite resin \\
Tetric N-Ceram Bulk Fill \\
in 3 increments (mesial, \\
distal and oclusal) \\
Class II cavity (MOD) with \\
insertion of composite resin \\
Tetric N-Ceram Bulk Fill \\
in a single increment
\end{tabular}

with a millimeter probe and silicone mold (Fig. 1). After completion of preparation, the cavities presented an occlusal box with $2.0 \mathrm{~mm}$ depth and $2.5 \mathrm{~mm}$ buccopalatal width, an a proximal box with $4 \mathrm{~mm}$ depth and $1.5 \mathrm{~mm}$ in the pulp direction (Fig. 1).

\section{Restorative Procedures}

In group I, a conventional incremental technique was used. The cavities were acid etched (Power Etching; BM4, Florianópolis, SC, Brazil) for $15 \mathrm{~s}$ in dentin and 30 s in enamel, rinsed for $60 \mathrm{~s}$ and the dentin was dried with a cotton pellet. The adhesive system (Tetric N-Bond; Ivoclar Vivadent) was then applied for $10 \mathrm{~s}$, the solvent was volatilized with air jet and the adhesive was light cured for $10 \mathrm{~s}$. The proximal boxes were restored using a boomerang-shaped metal matrix adapted to a Tofflemire retainer. Composite resin Tetric N-Ceram (Ivoclar Vivadent) was inserted at oblique increments of up to $2 \mathrm{~mm}$ diameter, contacting only two walls in each increment. After, the occlusal box was restored with increments. Each increment was light cured separately for $10 \mathrm{~s}$ according to the manufacturer's recommendations using a light curing unit Radii (SDI, Bayswater

Victoria, Australia) and a light intensity of 1,000 $\mathrm{mW} / \mathrm{cm}^{2}$. The final increments reproducing the occlusal enamel were molded using a silicone guide fabricated

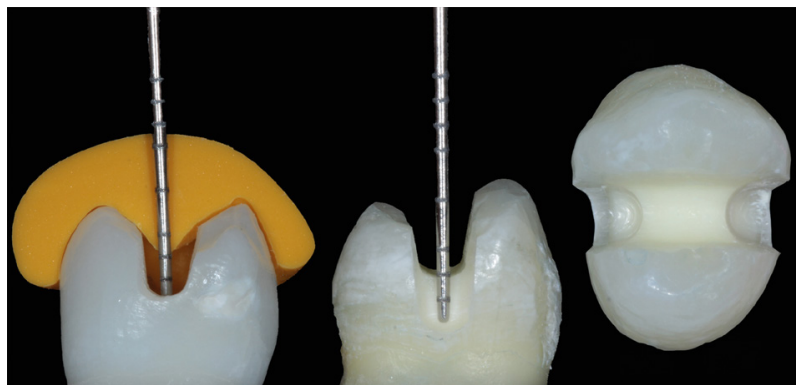

Figure 1. Sample preparation.

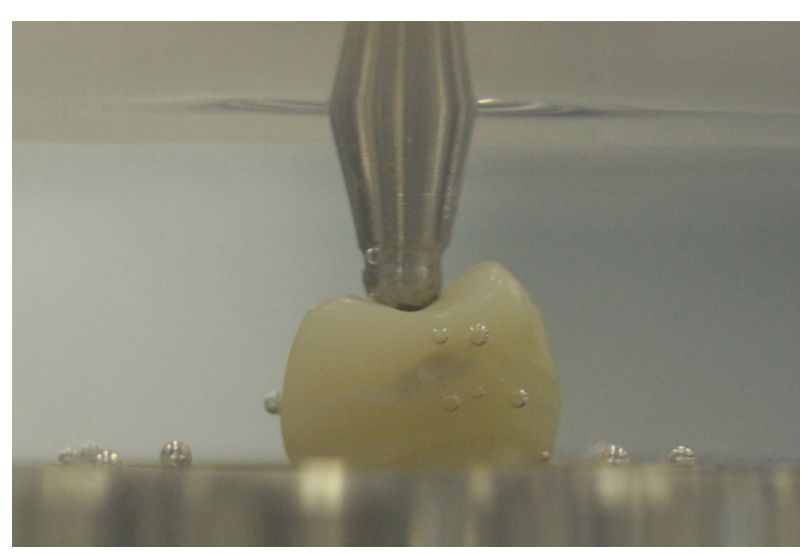

Figure 2. Sample positioned for fatigue testing. 
using a previous occlusal stent. Thus, the final restoration presented the same occlusal morphology as the unprepared sound teeth. A water-based oxygen inhibitor gel was applied on the surface of the restoration prior to the final polymerization. Finishing and polishing were performed using a polishing system (Ivoclar Vivadent).

In group BF3, the same bonding procedures described for group I were performed. However, the bulk fill composite resin (Tetric N-Ceram Bulk Fill; Ivoclar Vivadent) was filled in 3 increments: first and second for reconstruction of proximal boxes to the level of marginal ridge giving rise to a Class I cavity and the third referent to occlusal surface. The occlusal surface was shaped with a silicone matrix. Each increment was light cured for $10 \mathrm{~s}$. For group BF1, the same bulk fill composite resin was inserted in a single increment and the occlusal surface was reproduced using a silicone matrix and light cured for $10 \mathrm{~s}$. Finishing and polishing procedures were performed as described for group I. Samples were stored in distilled water at $37^{\circ} \mathrm{C}$ for 7 days before fatigue testing.

\section{Fatigue Testing}

The fatigue test was conducted at the Laboratory of Biomechanical Engineering of the Federal University of MN, USA) was used to load the samples with a 3-mmdiameter stainless steel sphere. Each sample was positioned on an adjustable plate base so that the load application sphere was located at the center of the occlusal surface and touched simultaneously the buccal and palatal cusps and the composite resin restoration. Occlusal contacts were tested using carbon articulating paper. The load chamber was filled with distilled water until complete immersion of specimens and maintained at $37^{\circ} \mathrm{C}$ throughout the experiment (Fig. 2).

The first stage of the fatigue test consisted of preconditioning the samples by applying sinusoidal loading with a force magnitude ranging from 50 to $200 \mathrm{~N}$ for 5,000 cycles. Then, stages of 30,000 load cycles were applied with the maximum force increasing gradually for each stage: 400,600,800, 1000, 1200 and $1400 \mathrm{~N}$ (10). The test was considered complete when 185,000 load cycles (the maximum number of loading cycles) were achieved or the specimen failed (Fig. 3). All stages of fatigue testing were performed with a load application frequency of $5 \mathrm{~Hz}$ and the number of cycles and fatigue-resistance load was recorded for each tooth.

A fracture analysis was performed by optical microscope at $\times 10$ magnification, fractures located above the CEJ were classified as restorable and below the CEJ as non-restorable fractures.

\section{Statistical Analysis}

The software SPSS Statistics 21 (IBM Corp., Armonk, NY, USA) was used to compare fatigue resistance of the groups using the Kaplan-Meier survival curve. The influence of the restorative technique/composite resin was observed by comparing the survival curves using the log-rank test at a 0.05 significance level.

\section{Results}

The mean load fatigue resistance for the control group (C), conventional composite incremental insertion (I) and bulk fill composite resin for both insertion techniques (BF1 and BF3) were respectively $1114.28,742.86 \mathrm{~N}, 685.71 \mathrm{~N}$ and $742.86 \mathrm{~N}$. No tooth from groups I, BF3 or BF1 withstood the maximum number of 185,000 cycles (survival=0\%). Only one tooth resisted 185,000 cycles in group C, but all of them reached a fatigue strength of at least $1000 \mathrm{~N}$.

A statistical analysis of the Kaplan-Meier survival

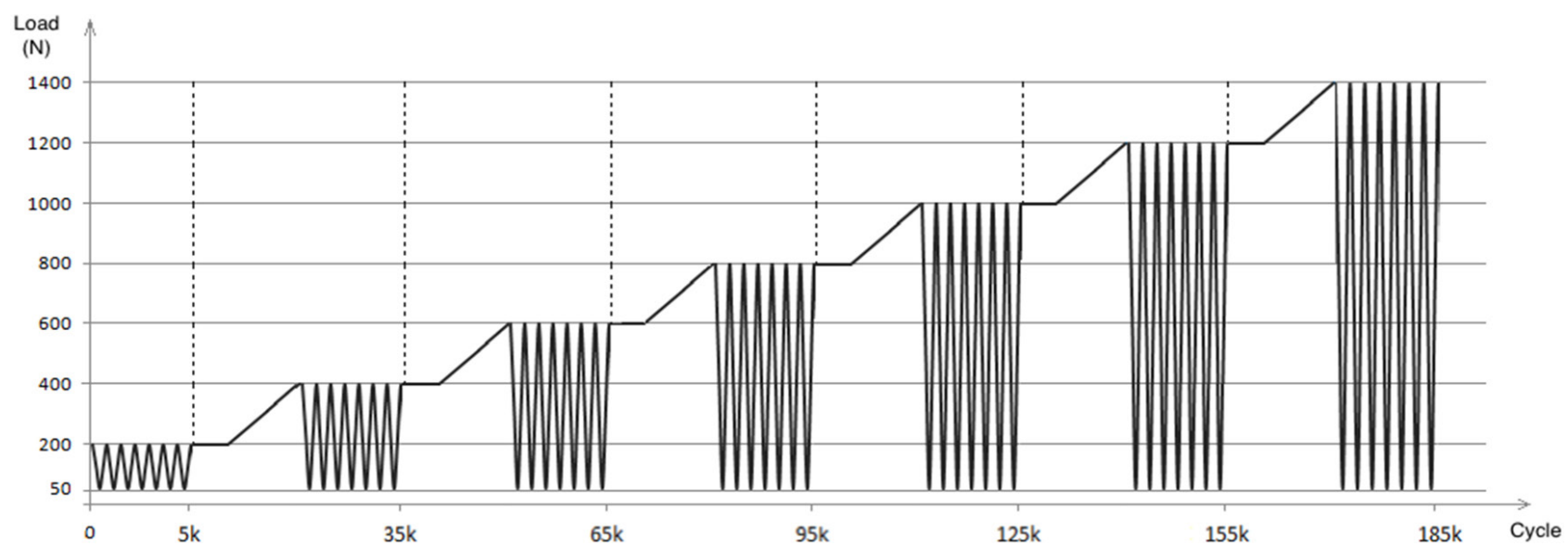

Figure 3. Loading curve. 
curve (Fig. 4) using the log-rank test showed a significant difference between group $\mathrm{C}$ and groups $\mathrm{I}, \mathrm{BF} 3$ and BF1 $(p=0.001)$. When only groups I, BF3 and BF1 were compared to each other, there was no significant difference $(p>0.05)$.

The fracture analysis demonstrated crescent values from the groups C (28.58\%) and I (42.85\%) up to BF1 and BF3 (85.71\% and $85.71 \%)$.

\section{Discussion}

The null hypothesis tested that there was no difference in fatigue resistance of teeth restored with incrementally inserted Tetric N-Ceram (I), bulk filled Tetric N-Ceram Bulk Fill in one and three increments (BF3 and BF1) and unprepared sound teeth $(C)$ was rejected $(p=0.001)$.

Several properties of bulk fill composites have been tested, such as polymerization shrinkage, polymerization depth, crack formation and bending resistance. One of the major reasons for restoration failure to occur is the accumulation of damage from cyclic loading (7). Because of this, the most important mechanical properties to be evaluated in a composite resin restoration include resistance to fracture, wear and fatigue (7).

The final test of any dental material must be a controlled clinical study. However, those are long lasting tests, which do not provide fast results. Therefore, biomechanical tests that simulate the oral environment by reproduction of the chewing forces, temperature and humidity of the oral cavity are important in evaluating the performance of new materials (8). Fatigue testing meets these requirements and is used for testing dental materials like composite resins and ceramics (9-21). The fatigue test simulates the clinical situation better than static compression test (11). Compressive strength values in sound maxillary premolars are approximately $1742 \pm 110 \mathrm{~N}$, although the current study presented an $1114.3 \pm 157 \mathrm{~N}$ mean value of fatigue strength in the control group (C) (22).

In this study, the antagonist tooth was simulated by a $3 \mathrm{~mm}$ diameter steel sphere, responsible for applying the loading forces at the contact interface between the tooth and the restorative material. To obtain the fatigue resistance values, the present study used a loading curve up to $1400 \mathrm{~N}$, as done by Magne and Knezevic (10), characterizing severe load for the tooth/restoration set. The applied frequency was $5 \mathrm{~Hz}$ in order to reduce the test execution time without causing localized heating of the sample or changes of its original mechanical properties. Episodes of chewing have a mean frequency of $1.57 \mathrm{~Hz}$, but the rhythm of chewing is specific to each individual and is stable over time (23). The storage and testing was conducted with samples immersed in water at $37{ }^{\circ} \mathrm{C}$, because mechanical strength of preconditioned samples in a dry environment is greater than those in a humid environment, due to degradation that occurs in the resin matrix in contact with water (24).

Statistical analysis of the Kaplan-Meier survival curve by the log-rank test showed significant differences between groups. Groups I, BF3 and BF1 obtained similar fatigue

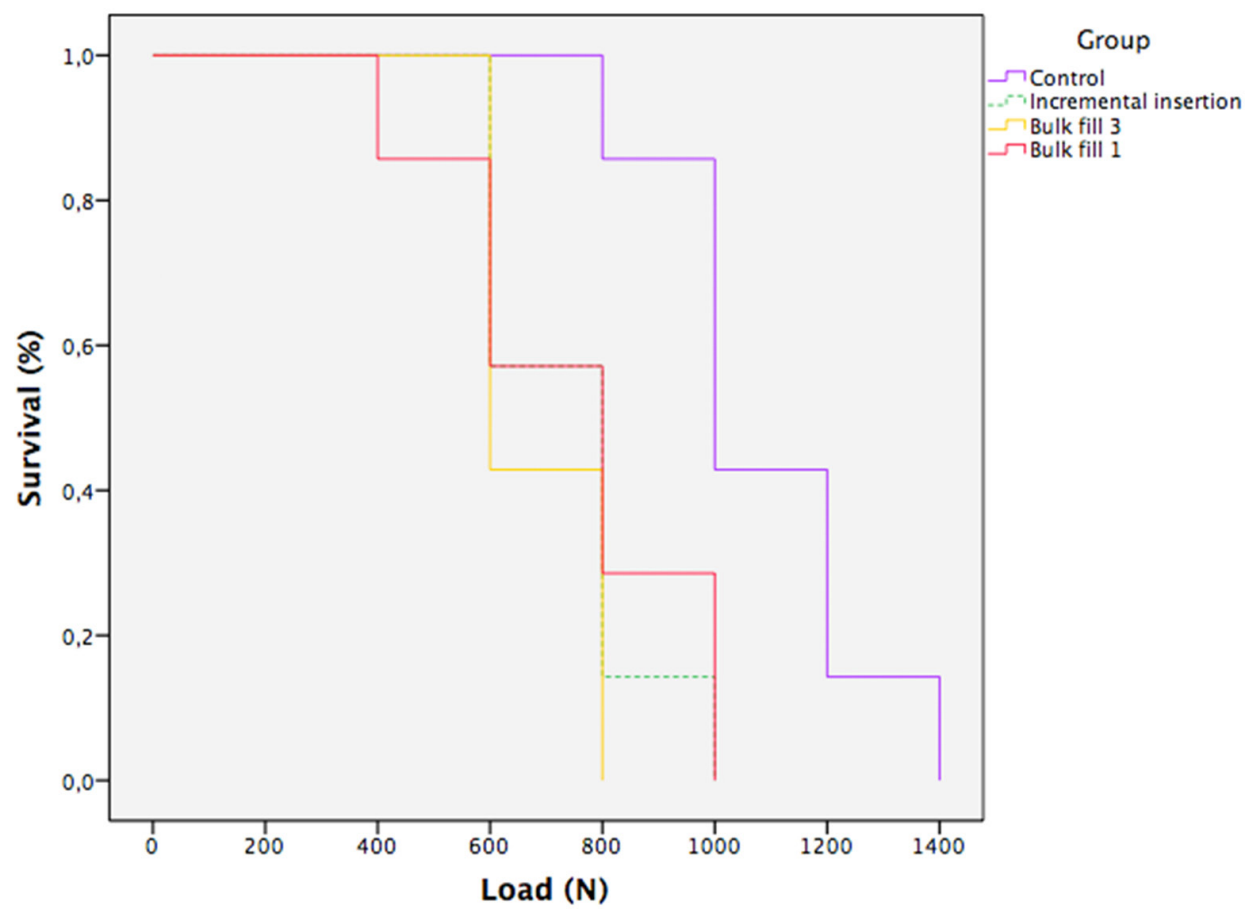

Figure 4. Survival scatter plot of specimens at each load stage. 
resistance, which was less that the resistance observed for group C. Teeth with class II cavities have decreased resistance to fatigue due to loss of tooth structure resulting from caries and the resulting cavity preparation. It is known that regardless of technique and characteristic of the material used, composite resin restorations are not capable of returning the tooth to its original strength, as recorded in the control group. However, the restored teeth presented good performance considering that the mean value for bite force in premolars ranges from 181-608 N (25). In cases with Angle Class I occlusion, the mean biting forces are $392 \pm 31.43 \mathrm{~N}(26)$.

The insertion of the bulk fill composite resin in a single increment (BF1) achieved similar performance to insertion of the same material in three increments (BF3). Indeed, this result proves the possibility of using this material in a single increment when considering the fatigue strength of tooth/restoration set. This possibility was tested because the insertion of bulk fill composite resin in a single increment into class II cavity could generate tension concentration in proximal boxes, weakening the set in this zone.

Observing the composite resins with different characteristics, the bulk fill resin placed in a single increment was found to have a fatigue resistance similar to restorations placed incrementally. Comparing the composition of the used composite resins, the amount of inorganic filler by volume varies only $2.5 \%$. The Tetric $\mathrm{N}$-Ceram resin contains $63.5 \%$ inorganic particles and Tetric $\mathrm{N}$-Ceram Bulk Fill resin contains 61\%. The composition of the organic matrix is basically the same. Tetric N-Ceram Bulk fill is characterized by particles with a low modulus of elasticity, which act neutralizing the forces of contraction during polymerization, ensuring a proper adaptation of the restoration material to cavity walls even in $4 \mathrm{~mm}$ increments (27).

Fracture analysis of teeth restored with bulk fill resin, independent of the insertion technique, showed a greater tendency for fracture below the CEJ (BF3: 85.71\% and BF1: $85.71 \%$ ) in comparison with a conventional resin placed using the incremental technique (42.85\%) and unprepared sound teeth $(28.58 \%)$. It is supposed that the insertion of conventional composite resin in increments created some voids at the adhesive interface between increments generated more failures above the CEJ.

Studies evaluating the formation of internal spaces in restorations (28) and cervical marginal integrity (29) demonstrate similar performance between bulk fill resin and conventional composites. Furthermore, the bulk fill technique has been shown to provide lower cusp strain, shrinkage stress and higher fracture resistance (30).

Based on the findings of this study, it may be concluded that (i) unprepared sound teeth presented higher fatigue resistance compared with teeth with restored class II cavities, regardless of the restorative material or cavity insertion technique; (ii) insertion of bulk fill composite resin in a single increment showed a similar fatigue resistance compared with its insertion in 3 increments; and (iii) bulk fill composite resin in a single increment showed a similar fatigue resistance to that of the conventional composite resin placed using the incremental insertion technique. However, they show higher amount of failure below the CEJ.

\section{Resumo}

0 objetivo deste estudo foi comparar a resistência à fadiga de dentes restaurados com uma resina composta bulk fill, resina composta convencional de inserção incremental e dentes hígidos sem preparo. Vinte e oito pré-molares maxilares extraidos foram selecionados e divididos em quatro grupos conforme a resina composta e técnica de inserção: controle (C), resina composta convencional com inserção incremental (I) e resina composta bulk fill inserida em três (BF3) ou único incremento (BF1). 0 preparo das cavidades foi padronizado para todos os grupos. As amostras foram restauradas e submetidas ao testes de resistência à fadiga com uma frequência de $5 \mathrm{~Hz}$. Foram aplicados 5.000 ciclos de carregamento senoidal inicial com valor de força mínima igual a $50 \mathrm{~N}$ e força máxima de 200 N. Após, foram aplicados estágios de 30.000 ciclos de carga com a força máxima sendo aumentada gradativamente a cada estágio, para 400 , $600,800,1000,1200$ e 1400 N. 0 ensaio foi finalizado ao ser alcançado 185.000 ciclos de carga (número máximo de ciclos de carga), ou na fratura da amostra. A resistência à fadiga foi registrada para comparação usando a curva de sobrevivência de Kaplan-Meier e analisada pelo teste log-rank a um nivel de significância de 0.05 . As fraturas foram classificadas conforme a posição da falha - acima ou abaixo da junção cemento esmalte (JCE). A análise estatística da curva de sobrevivência de Kaplan-Meier pelo teste log-rank demonstrou diferença significativa entre os grupos ( $p=0.001)$. $\mathrm{Na}$ análise de fratura somente $28.58 \%$ das falhas foram abaixo da JCE para o grupo C, enquanto para os grupos I, BF1 e BF3 foram 42.85\%, $85.71 \%$ e $85.71 \%$, respectivamente. Os dentes restaurados com a resina composta bulk fill em ambas as técnicas de inserção apresentaram valores de resistência à fadiga similares àqueles dos dentes restaurados com a resina composta convencional pela técnica incremental. Entretanto, dentes hígidos mostraram uma menor porcentagem de fraturas abaixo da JCE e maior resistência à fadiga.

\section{References}

1. El-Damanhoury HM, Platt JA. Polymerization shrinkage stress kinetics and related properties of bulk-fill resin composites. Oper Dent 2014;39:374-382.

2. Garcia D, Yaman P, Dennison J, Neiva GF. Polymerization shrinkage and depth of cure of bulk fill flowable composite resins. Oper Dent 2014;39:441-448.

3. DeLong $\mathrm{R}$, Douglas WH. An artificial oral environment for testing dental materials. IEEE Trans Biomed Eng 1991;38:335-345.

4. Lohbauer U, Von der Horst T, Frankenberger R, Kramer N, Petschelt A. Flexural fatigue behavior of resin composite dental restoratives. Dent Mater 2003;19:435-440.

5. Lin L, Drummond JL. Cyclic loading of notched dental composite specimens. Dent Mater 2010;26:207-214.

6. Takeshige F, Kawakami Y, Hayashi M, Ebisu S. Fatigue behavior of resin composites in aqueous environments. Dent Mater 2007;23:893-899.

7. Ferracane JL. Resin-based composite performance: Are there some things we can't predict? Dent Mater 2013;29:51-58.

8. DeLong R, Douglas WH. Development of an artificial oral environment for the testing of dental restoratives: Bi-axial Force and Movement Control. J Dent Res 1983;62:32-36.

9. Garoushi S, Lassila LVJ, Tezvergil A, Vallittu PK. Static and fatigue compression test for particulate filler composite resin with fiber- 
reinforced composite substructure. Dent Mater 2007;23:17-23.

10. Magne $P$, Knezevic $A$. Simulated fatigue resistance of composite resin versus porcelain CAD/CAM overlay restorations on endodontically treated molars. Quintessence Int 2009;40:125-133.

11. Kujis RH, Fennis WMM, Kreulen CM, Roeters FJM, Verdonschot $N_{\text {, }}$ Creugers NHJ. A comparison of fatigue resistance of three materials for cusp-replacing adhesive restorations. J Dent 2006;34:19-25.

12. Fennis WMM, Kuijs RH, Kreulen $C M$, Verdonschot $N$, Creugers NHJ. Fatigue resistance of teeth restored with cuspal-coverage composite restorations. Int J Prosthodont 2004;17:313-317.

13. Cubas GBA, Habekost L, Camacho GB, Pereira-Cenci T. Fracture resistance of premolars restored with inlay and onlay ceramic restorations and luted with two different agents. J Prosthodont 2011;55:53-59.

14. Clausen J-O, Tara MA, Kern M. Dynamic fatigue and fracture resistance of non-retentive all-ceramic full-coverage molar restorations. Influence of ceramic material and preparation design. Dent Mater 2010;26:533-538.

15. Attia A, Kern M. Influence of cyclic loading and luting agents on the fracture load of two all-ceramic crown systems. J Prosthet Dent 2004;92:551-556.

16. Habekost LV, Camacho GB, Pinto MB, Demarco FF. Fracture resistance of premolars restored with partial ceramic restorations and submitted to two different loading stresses. Oper Dent 2006;31:204-211.

17. Magne $P$, Schlichting $L H$, Maia $H P$, Baratieri $L N$. In vitro fatigue resistance of CAD/CAM composite resin and ceramic posterior occlusal veneers. J Prosthet Dent 2010;104:149-157.

18. Stappert CFJ, Chitmongkolsuk S, Silva NRFA, Strub JR W. Effect of mouth-motion fatigue and thermal cycling on the marginal accuracy of partial coverage restorations made of various dental materials. Dent Mater 2008;24:1248-1257.

19. Batalha-Silva S, Andrada MAC, Maia HP, Magne P. Fatigue resistance and crack propensity of large MOD composite resin restorations: Direct versus CAD/CAM inlays. Dent Mater 2013;29:324-331.

20. Shibata $S$, Gondo R, Araújo E, Roesler CRM, Baratieri LN. Influence of surrounding wall thickness on the fatigue resistance of molars restored with ceramic inlay. Braz Oral Res 2014;20:1-8.
21. Ambica K, Mahendran K, Talwar S, Verma M, Padmini G, Periasamy R. Comparative evaluation of fracture resistance under static and fatigue loading of endodontically treated teeth restored with carbon fiber posts, glass fiber posts, and an experimental dentin post system: an in vitro study. J Endod 2013;39:96-100.

22. Akbarian $\mathrm{G}$, Ameri $\mathrm{H}$, Chasteen JE, Ghavamnasiri M. Fracture resistance of premolar teeth restored with silorane-based or dimethacrylatebased composite resins. J Esthet Rest Dent 2014;26:200-207.

23. Po JMC, Kieser JA, Gallo LM, Tésenyi AJ, Herbison P, Farella M. Timefrequency analysis of chewing activity in the natural environment. $J$ Dent Res 2011;90:1206-1210.

24. Braem M, Lambrechts $P$, Vanherle SG. Clinical relevance of laboratory fatigue studies. J Dent 1994;22:97-102.

25. Widmalm S-E, Ericsson SG. Maximal bite force with centric and eccentric load. J Oral Rehab 1982;9:445-450.

26. Sathyanarayana HP, Premkumar S, Manjula WS. Assessment of maximum voluntary bite force in adults with normal occlusion and different types of malocclusions. J Contemp Dent Pract 2012;13:534538.

27. http://www.ivoclarvivadent.com.br/pt-br/compositos/tetric-n-cerambulk-fill accessed on 2015 October 7.

28. Furness A, Taros MY, Looney SW, Rueggeberg FA. Effect of bulk/ incremental fill on internal gap formation of bulk-fill composites. J Dent 2014;42:439-449.

29. Al-Harbi F, Kaisarly D, Bader D, El Gezawi M. Marginal integrity of bulk versus incremental fill class II composite restorations. Oper Dent 2016:41:146-156.

30. Rosatto CMP, Bicalho AA, Veríssimo C, Bragança MP, Rodrigues MP, Tantbirojn $D$, et al.. Mechanical properties, shrinkage stress, cuspal strain and fracture resistance of molars restored with bulk-fill composites and incremental filling technique. J Dent 2015;43:15191528.

Received February 17, 2016 Accepted May 20, 2016 